удк 330.33

\title{
ПОНОМАРЕНКО Марина Михайлівна
}

Київський коледж транспортної інфраструктури

пров. Ярослава Хомова (Островського), буд. 16, Київ, Україна, 03035

e-mail: Ponomarenko_M@ukr.net

https://orcid.org/0000-0001-6493-3350

\section{РОЗВИТОК ПОЛІТИЧНОЇ ЕКОНОМІЇ, ЯК НАУКИ В РОСІЙСЬКІЙ ІМПЕРІЇ В ДРУГІЙ ПОЛОВИНІ ХІХ - НА ПОЧАТКУ ХХ СТОЛІТТЯ}

Анотація. У 2015 році політичній економії виповнюється 400 років з часів ї̈ виникнення та початку становлення, як окремої науки. Це достатній термін для того, щоб робити узагальнюючі висновки але ці висновки неоднозначні.

Політична економія, як наука сформувалася в результаті історичного розвитку вихідного економічного відношення - спільно-розділеної праці, що є предметом вивчення політичної економії. Розкрито основні історичні етапи розвитку політичної економії як науки в Україні, об'єктивні основи існування періодів ї̈ деактуалізаціі $i$ нової актуалізації, місце в системі економічних наук, єдність $і$ відмінність предметів $i$ методів політичної економії та інших складових економічної теорії.

Ключові слова: політична економія; становлення і розвиток політичної економії; українські економісти ХІХ ст.; зародження політичної економії в Україні; Київська політекономічна школа; політична економія, як навчальна дисципліна; Харківська політекономічна школа

У періоди трансформаційних перетворень суспільство являє собою особливо привабливий об'єкт для соціально-економічних досліджень. Таким воно було в Російській імперії після реформ XIX ст. Таким є в Україні сьогодні. Теоретичні досягнення економістів 2-ї половини XIX - перших десятиліть XX ст. поступово набували світове визнання.

Оцінюючи розвиток економічної науки у першій половині XIX ст., можна сказати, що цей період знаменувався домінуванням ідей класичної теорії. Проте, саме в цей час, в межах класичної школи розпочинається поділ на англійську та французьку гілки, що безумовно збагатило класичну теорію і сприяло її науковому розвитку, але одночасно посилило суперечності всередині самої школи. Загострення соціальних проблем та економічні кризи, що періодично виникали, дали поштовх до виникнення критичних напрямків в межах класичної школи, а також до формування альтернативних напрямів економічної теорії.

Економічна наука в Україні має багатовікові традиції. Однак вивчення багажу наукової спадщини національної економічної науки фактично дотепер залишається незвершеним. Поодинокі згадки про вітчизняних економістів зустрічаються у небагатьох наукових публікаціях. Більшість творів українських економістів донині залишають у запасниках та 
сховищах і відомі вузькому колу дослідників. Та й відомі українські науковці передусім закордоном, а невідомими залишаються на Батьківщині.

Українські землі ще з часів Київської Русі більше у своєму розвитку тяжіли не до Сходу, а Заходу, переймаючи у нього прогресивні ідеї. На Україні існували міцні просвітницькі традиції, освіта була поширена і рівні початкової, і на рівні вищої (Острозька академія, Києво-Могилянська академія) [1].

Зародилась економічна наука в Україні паралельно 3 їі західноєвропейськими аналогами. Однак в силу подальшого гальмування господарського розвитку розвивалась більш повільно, а твори написані українськими науковцями тривалий період залишались маловідомими.

Етапи розвитку української політичної економії

\begin{tabular}{|c|c|c|}
\hline $\begin{array}{c}\text { Напрями } \\
\text { економічної думки }\end{array}$ & Період & Основні представники та пам'ятки \\
\hline $\begin{array}{c}\text { Економічна } \\
\text { думка } \\
\text { середньовіччя } \\
\end{array}$ & V - XV ст. & 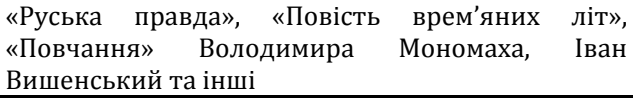 \\
\hline Меркантилізм & XV -XVIII ст. & $\begin{array}{l}\text { Б. Хмельницький, Ф. Прокопович, С. Оріховський, } \\
\text { І. Гізель }\end{array}$ \\
\hline $\begin{array}{l}\text { Класична } \\
\text { політична } \\
\text { економія }\end{array}$ & $\begin{array}{l}\text { др. пол. XVII- } \\
\text { др. пол. XIX ст. }\end{array}$ & $\begin{array}{l}\text { Григір Сковорода, Яків Ковельський, Т. Снепанов } \\
\text { «Записки про політичну економію», I. } \\
\text { Вернадський «Предмет політичної економії», М. } \\
\text { Вольський «Завдання політичної економії і } \\
\text { відношення її до інших наук»та інші }\end{array}$ \\
\hline $\begin{array}{c}\text { Соціалістичні } \\
\text { вчення }\end{array}$ & $\begin{array}{c}\mathrm{XV} \text { - др. пол. XIX } \\
\text { ст. }\end{array}$ & $\begin{array}{l}\text { М.Драгоманов «Попереднє слово» до першого } \\
\text { числа збірки «громади», В. Навроцький } \\
\text { «подвійна крейда», О.Терлецький «Лихва на } \\
\text { Буковині», І.Франко «Що таке поступ» та інші }\end{array}$ \\
\hline $\begin{array}{l}\text { Фізична } \\
\text { політична } \\
\text { економія }\end{array}$ & XVIII - XIX ст. & $\begin{array}{l}\text { С. Подолинський «Про бідність», «Парова } \\
\text { машина», «Життя і здоров’я людей на Україні», } \\
\text { «Ремесла і фабрики на Україні», «Труд человека и } \\
\text { его отношение к распределению энергии» та } \\
\text { інші }\end{array}$ \\
\hline Маржиналізм & $\begin{array}{l}\text { 60-90-ті pp. } \\
\text { XIX ст. }\end{array}$ & $\begin{array}{l}\text { М.Бунге «Основи політичної економії», Д.Піхно } \\
\text { «Закон попиту та пропозиції. До теорії цінності» } \\
\text { «Залізничні тарифи», А.Антонович «Теорія } \\
\text { цінності», М.Коссовський «Цінність і ціна», Р. } \\
\text { Оржецький «Корисність і ціна. Політико- } \\
\text { економічний нарис», О.Білімович «До питання } \\
\text { про розцінку господарських благ»та інші }\end{array}$ \\
\hline Неолібералізм & $\begin{array}{l}90-\text { ті рр.XIX- } \\
90 \text { рр. XX ст. }\end{array}$ & $\begin{array}{l}\text { Є.Слуцький «Теорія кореляції і елементи вчення } \\
\text { про криві розподілу», «До теорії збалансованого } \\
\text { бюджету споживача», М. Туган-Барановський } \\
\text { «Основи політичної економії» та інші }\end{array}$ \\
\hline Інституціоналізм & $\begin{array}{l}\text { кн. XIX- } \\
\text { XX ст. }\end{array}$ & $\begin{array}{l}\text { М. Бунге, M.І. Туган-Барановський, Д. Піхно, } \\
\text { С. Булгаков, М. Ковалевський та інші }\end{array}$ \\
\hline
\end{tabular}


У XIX ст. в Україні працювало декілька економістів-аграрників, які зібрали статистичний матеріал, проаналізували його і зробили поради 3 удосконалення економічного розвитку. Відомими дореформеними економістами були Володимир Каразін (1773-1842) і Дмитро Жуковський (1810-1856). В. Каразін засновник Харківського університету, виступав як прихильник реформаторського напрямку поширення капіталізму. Він виступав за аграрну реформу: довічне наділення селян землею, а в поміщицьких помістях використовувати найману працю. Пропонував заходи скорочення зовнішнього боргу держави, за державне сприяння промисловості. Д. Жуковський аналізував поміщицьке господарство і вказав на його неефективність через використання праці кріпаків [2]. Доводив, що праця найманих робітників у 4 рази ефективніша за кріпосну. Вчений аналізував позитивні й негативні сторони крупних і дрібних підприємств, в результаті чого приходить до висновку, що пріоритетними для України є дрібні господарства, але за умов державної підтримки. Основну причину відсталості української промисловості вбачав у нерозвиненості внутрішнього ринку, зубожіння населення і відсутність шляхів сполучення.

Після реформи 1861 року в Україні набуває поширення громадівський рух. Відомим представником цього руху був Михайло Драгоманов $(1841$ 1895). вчений виступав за панслав'янізм - об'єднання слов'ян. У ринковому механізмі виділив позитивне i негативне: надмірна диференціація населення за рівнем доходу і власністю. М. Драгоманов як соціаліст виступав за знищення приватної власності.

Сергій Подолинський (1850 - 1891) заснував фізичну політичну економію. У творі “Ремесла і фабрики на Україні” стверджує, що капіталізм на Україні проходить 3 стадії: ремесло, мануфактура, фабрика. У статті “Про бідність" в популярній формі викладає теорію марксизму.

До середини XIX ст. посилилась дискусія та сперичання між представниками різних течій та шкіл, яка підігрівалась виникненням нових соціально-господарських проблем, як теоретичного та i прикладного характеру. Все це сприяло надзвичайно бурхливому та багатовекторному подальшому розвитку української економічної науки. У першій половині XIX ст. політична економія поширилась із Західної Європи, центру свого розвитку, на інші країни, зокрема Російську імперію, до складу якої на той час входила значна частина України. Процес розвитку політичної економії на просторах Російської імперії «не тільки відбив всю суперечливість процесу еволюції і теоретико-методологічної перебудови іiі на Заході, але й суттєво відрізнявся від нього» [3]. Ці особливості були пов'язані із своєрідністю і особливістю соціальноекономічного розвитку Російської імперії.

На нашу думку, правомірно на основі застосування критеріїв визначення наукової школи поставити питання про школу української 
управлінської думки та її відомих представників (основоположника школи М. Бунге, послідовників - А. Антоно- вича, Д. Піхна, М. Цитовича, К. Гаттенбергера, В. Левитського, Г. Цехановецького, М. ТуганБарановського, П. Шейміна, М. Шпилевського, М. Куплеваського та ін.). Відмітимо найважливіші характерні ознаки школи: розгляд об'єкта i предмета управлінської науки у взаємозв'язку матеріального та не матеріального виробництва, єдності дедуктивного та індуктивного методів дослідження; обгрунтування можливості та необхідності розширення втручання держави в економіку; аналіз єдності та взаємодії держави і суспільства у забезпеченні майнової та особистої безпеки і народного добробуту; розгляд еволюції управлінської думки від концепцій поліції, поліцейської держави до культурної держави; конвергентний характер розвитку науки (синтез ключових положень класичної політекономії, історичної школи, інституціоналізму, соціал-реформізму) та iн.

Питання про київську наукову школу в політичній економії вперше поставив і обгрунтував у 1913 р. професор Київського університету О.Д. Білімович. Дослідження відомих вітчизняних учених (С.М. Злупко, Л.Я. Корнійчук, Л.П. Горкіна, В.В. Небрат, П.І. Юхименко та ін.) поглибили розуміння причин виникнення, суті, особливостей поглядів представників цієї наукової школи, проте не привели до неоднозначних і несуперечливих трактувань питань [4].

У повній мірі такий висновок відноситься i до поглядів тих західноєвропейських вчених, які поділяють думку про існування київської політико-економічної школи, основоположником якої справедливо вважається М. Бунге, а ї найвідомішими представниками - учні та послідовники вченого (Д. Піхно, А. Антонович, Ю. Янсон, М. Цитович та ін.).

Відомий німецький вчений Й. Цвайнерт в своїй праці писав. Що вирішальну відмінність між київською і московською школами в галузі економічної теорії вбачає у запереченні київськими економістами (за винятком I.B. Вернадського) трудової теорії вартості. У галузі економічної політики вирішальними відмінностями київської школи Й. Цвайнерт вважає:

-по-перше, «неприйняття соціалізму»,

-по-друге, «переконаність, сприйняту від «молодшої» історичної школи, про можливість пом'якшити небажані соціальні наслідки капіталізму за допомогою державної соціальної політики». Головну причину спадкоємності в економічному мисленні представників київської школи Й. Цвайнерт вбачає в уникненні Київським університетом того «руйнівного впливу, якого російська ліва інтелігенція і особливо Чернишевський вчинили на економічну науку в Центральній Росії». Поряд 3 тим, пише німецький дослідник, певну роль відіграв реальний 
історичний розвиток, а саме більш ранній розпуск в Україні общини i, як наслідок, суттєве зростання продуктивності праці [5].

Значне місце в політичній економії Росії (на відміну від Заходу) посідали аграрні питання i, зокрема, проблема общини. У вирішенні аграрного питання намітились два основні напрями. Представники одного - прямо обстоювали поміщицький шлях аграрної еволюції. Представники іншого - виступали з критикою аграрної політики царизму, вказували на тяжке становище селянства, критикували способи ведення поміщицького господарства, проте, фактично, виступали за його збереження.

До цього (ліберально-народницького) напряму належала значна частина російських економістів. Він переважав у політекономії в пореформений період.

Представники цього напряму виходили з ідей А. Сміта і Д. Рікардо. Цікаво, що вони прихильно ставились до економічної теорії К.Маркса, розглядаючи її як розвиток класичної теорії. Ідеї цього напряму набрали найбільшого розвитку в працях М.О. Каблукова (1849-1919), О.С. Посникова (1846-1921), О. І. Чупрова (1842-1908), М. О. Каришева (1855-1905) та інших, праці котрих було значною мірою присвячено аграрним проблемам. Основу аграрної програми цих економістів становили: заперечення капіталістичної еволюції сільського господарства, захист общинного землеволодіння і збереження поміщицької земельної власності.

Каблуков, наприклад, усіляко захищав відробітки як форму поєднання інтересів поміщиків і селян. У центрі уваги Посникова була проблема збереження общини, розширення їі меж за рахунок державних земель. Програмою професора Московського університету Чупрова передбачалось збереження общини, запровадження раціональнішої землеробської культури, розвиток кустарних промислів тощо [6].

Хоч аграрні питання займали значне місце в працях лібералнародницьких економістів, ними не вичерпувались їхні наукові інтереси. Так, у Чупрова ми бачимо весь спектр питань політичної економії, а також конкретної економіки і теоретичної статистики.

Теоретичну позицію Чупрова в політичній економії марксистська література трактує як еклектичну, передовсім на тій підставі, що він визнавав наявність кількох шкіл у політичної економї і бачив певні позитивні риси в кожній із них. Виділяючи такі школи, як манчестерська, соціалістична й історична, Чупров підкреслював, що «за неупередженого погляду на справу в кожній із трьох шкіл виявляється своя частка істини».

Політичну економію він розглядав як науку про вічні закони, що діють на всіх етапах історичного розвитку, в усіх суспільно-економічних формаціях. Саме тому він мріяв про поєднання всіх напрямків політичної економії, про створення єдиної економічної науки, що керується єдиними істинами. У своїх перших працях і своєму першому курсі лекцій (1875р.) 
Чупров виступає як прихильник теорії класиків політичної економії, i зокрема трудової теорії вартості. «Стосовно основного положення політичної економії, встановленого Адамом Смітом і Рікардо, - писав він, мінова вартість кожного предмета визначається кількістю праці, витраченої на його виготовлення» [7].

У лекціях і ранніх працях Чупров використовує певні положення економічної теорії Маркса, але досить еклектично трактує економічні категорії з позицій різних напрямків політичної економії. Капітал у нього результат ощадливості, як у Т. Мальтуса та інших. Робочий час він (як і Маркс) розділяє на необхідний і додатковий, погоджуючись, що маса продуктів, котра створюється в додатковий час, «становитиме прибуток капіталістів». Причому він підкреслює, що «будь-яке збільшення додаткового часу підвищить прибуток i, навпаки, зменшення знизить». У такому трактуванні прибуток виступає як результат додаткової праці робітників. Утім О. Чупров розглядає прибуток і як плату капіталістам за управління підприємством, за ризик вкладання капіталу, як процент на вкладений капітал [8].

Аналізуючи зародження теорії корисності, 0. Чупров, проте, вважає її другорядною і виступає як прихильник класичної політекономії з теорією трудової вартості. Другорядне значення теорії корисності він пояснював неможливістю безпосереднього порівнювання благ за їхніми фізичними властивостями та суб'єктивним характером оцінок корисних властивостей тих чи інших предметів. На цій підставі він робив висновок, що мінові пропорції товарів визначаються не корисністю, а кількістю праці «...необхідної для виготовлення цих самих товарів». На таких самих позиціях стояли Каблуков і Каришев, які підкреслювали величезну роль праці в господарському житті.

На захист трудової теорії вартості і з критикою теорї корисності виступив А. О. Ісаєв (1851-1924). Він пропонує відмовитись від категорії граничної корисності і зосередитись на категорії корисності, яку досліджували ще економісти-класики. Гранична корисність, підкреслював він, зв'язана з діяльністю особи, несе на собі відбиток її власних інтересів, а не суспільного середовища. Що ж до категорії корисності взагалі, то «саме в понятті про неї знаходить вираз суспільно визнана придатність благ служити людським потребам». Критикуючи суб'єктивну теорію цінності, В. Ісаєв був прихильником марксистського трактування вартості. Він пише про «економічну версію вартості», згідно з якою величина вартості визначається суспільно необхідним робочим часом відповідно до розмірів суспільної потреби в тому чи іншому продукті [9].

Еволюція суспільно-економічних відносин у Росії, розвиток політичної економії на Заході не могли не позначитись на політекономії в Росії. Якщо в пореформений період вплив класичної політичної економії на російських економістів був досить значним, що пояснювалось антикріпосницькою 
спрямованістю наукових праць останніх, то поступово становище змінюється. Наприкінці XIX - на початку XX ст. перед економістами постають нові проблеми, нові завдання. Значного розвитку набуває теоретична розробка економіки окремих галузей виробництва. Змінюється і сама проблематика політичної економії. Замість детального аналізу економічних категорій на перший план виходять питання економічної політики. Посилюється вплив нових напрямків політичної економії Заходу, зокрема австрійської школи та німецької історичної школи. Причому цей вплив не був однобічним. Російські економісти розробляли низку проблем у руслі цих напрямів і здобули високу оцінку на Заході [10].

У кінці XIX і на початку XX ст. в політичній економї Росії набувають значного поширення нові напрями. Складається так званий соціальний напрям (соціальна школа) політичної економії, представники якого соціальне протиставляли матеріальному i на перший план висували правові, етичні відносини людей. Цей напрям був репрезентований такими економістами, як С. Солнцев, П. Струве та інші. Формуються також психологічний та математичний напрями. Психологічний напрям почав формуватися в працях українських економістів і згодом поширився в Росії. Його представники розвинули далі суб’єктивну теорію цінності, запровадили поняття об’єктивної й суб'єктивної господарської цінності, поширили суб'єктивні принципи психології окремої людини на психологію «колективності», застосовуючи такі поняття, як «соціальні оцінки», «суспільна гранична корисність». Один із представників цього напряму (В. C. Войтинський) пропагував поєднання психологічного напряму 3 історичним. «Примирення історизму з психологізмом, - писав він, здається нам надзвичайно важливим, тому що лише історикопсихологічний метод дає можливість розв'язувати ті теоретичні соціально-економічні проблеми, над вирішенням яких безплідно б’ється економічна думка вже друге століття».

Основи математичної школи в Росії заклав Чупров, хоча інтерес до цього напрямку виник іще в 60-х рр., коли в журналі «Отечественные записки» за підписом «А.Ч.» було надруковано статтю «Математичне обчислення ціни праці». Автор статті пропагував ідеї німецького статистика Енгеля в якій він підкреслював плодотворність застосування математичного методу до вивчення економічних явищ. Значний внесок у розробку математичних методів у Росії зробили такі економісти, як Ю. Г. Жуковський, В. К. Дмитрієв, Л. З. Слонімський та інші. Так, Ю. Жуковський з допомогою цих методів намагався дати аналіз теорії прибутку і теорії ренти Д. Рікардо. Л. Слонімський пропагував ідеї І. Тюнена і А. Курно. 3 викладенням найцінніших, на його погляд, досягнень математичної школи виступив Л. Вінярський. 
Праці відомого економіста-математика В. Дмитрієва справили значний вплив на розвиток економіко-математичних досліджень не тільки в Росії, а й за кордоном. Головна мета його економічних нарисів - довести сумісність трудової теорії і теорії граничної корисності. Він першим запропонував спосіб визначення повних витрат праці на виробництво продукції і поєднав аналіз виробничих витрат із аналізом ціни та їі залежності від попиту і пропозиції $[11,12]$.

У першому нарисі Дмитрієв дає математичний аналіз теорії цінності Д. Рікардо, розглядає питання кількісного аналізу співвідношення між ціною і витратами виробництва і робить цікаві висновки щодо визначення повних витрат праці. У другому нарисі він аналізує теорію конкуренції А. Курно, у третьому - викладає еволюцію теорії граничної корисності.

Однак математичний напрям не набрав у Росії великого поширення, багато економістів критикувало математичну школу.

Отже, можна сказати, що розвиток політичної економії в Російській імперії хоч і мав певні особливості, зумовлені особливостями соціальноекономічного розвитку країни, проте в цілому відбувався в тому самому напрямку, що й на Заході.

\section{Джерела та література}

1. Горкіна Л.П. Туган-Барановський в економічній теорії та історії. К., 2001. 268 с.

2. Корнійчук Л.Я. Історія економічної думки України. К.: КНЕУ, 2004. 432 с.

3. Васильєва Р.Х., Горкіна Л.П., Петровська Н.А. Історія економічної думки України. К.: Либідь, 1993. 272 с.

4. Леоненко П.М. Методологічні аспекти історії української економічної думки (XIX XX ст.). К.: IAE УАAН, 2004. 434 с.

5. Леоненко П.М., Юхименко П.І. Економічна історія. К.: Знання. Прес, 2004. 496 с.

6. Корнійчук Л.Я., Татаренко Н.О., Поручник А.М., Ткаченко О.В., Кирилова Г.Ю. Історія економічних учень. К.: КНЕУ, 2005. 562 с.

7. Коропецький I.С. Українські економісти XIX ст. та західна наука. К., 1993.192 с.

8. Історія економічних учень / За ред. В. Базилевича. К.: Знання, 2004. 1300 с

9. Шевчук В. Українська економічна думка на тлі сучасного цивілізаційного розвитку. Collection of scholarly papers. / Published by the Ukrainian Free University in Munich. Reihe: Studia. Band 18. München L'viv, 1996. C. 48-66.

10. Шеремет А.Д., Майданчик Б.И. Актуальные вопросы развития экономического анализа в 80-е годы. Бухгалтерский учет. 1981. № 6. С. 26-27.

11. Политическая экономия: прошлое, настоящее, будущее. Часть I.: монографія. К.: ЦУЛ, 2014. 494 c.

12. Политическая экономия: прошлое, настоящее, будущее. Часть II. монографія / под. ред. В.М. Гейца, В.Н. Тарасевича. К.: ЦУЛ, 2014. 566 с.

\section{Пономаренко Марина Михайловна}

Киевский колледж транспортной инфраструктуры

пер. Ярослава Хомового (Островского), д. 16 Киев, Украина, 03035 


\section{Развитие политической экономии, как науки в Российской империи во второй половине XIX - начале XX века}

Анотация. В 2015 году политической экономии исполняется 400 лет со времен ее возникновения и начала становления как отдельной науки. Это достаточный срок для того, чтобы делать обобщающие выводы но эти выводы неоднозначны.

Политическая экономия как наука сформировалась в результате исторического развития исходного экономического отношение - совместно-разделенной труда, является предметом изучения политической экономии. Раскрыты основные исторические этапы развития политической экономии как науки в Украине объективные основы существования периодов ее деактуализации и новой актуализации, место в системе экономических наук, единство и различие предметов и методов политической экономии и других составляющих экономической теории.

Ключевые слова: политическая экономия; становление и развитие политической экономии; украинские экономисты ХІХ ст.; зарождение политической экономии в Украине; Киевская политэкономическая школа; политическая экономия, как учебная дисципліна; Харьковская политэкономическая школа

\section{Ponomarenko Marina}

Kyiv College of Transport Infrastructure

16, lane Yaroslav Khomovy (Ostrovsky), Kyiv, Ukraine, 03035

\section{Development of political economy as a science in the Russian Empire in the second half of the nineteenth and early twentieth centuries}

Abstract. In 2015, political economy, as a science, dates back 400 years since the emergence and the beginning of its formation, as a separate science. This is a sufficient period for making general conclusions, but these conclusions are ambiguous. Political economy, as science was formed as a result of historical development of the initial economic relations socially divided labor, which is the subject of studying political economy. The main historical stages of the development of political economy as a science in Ukraine are revealed, the objective foundations of the existence of periods of its de actualization and new actualization, and a place in the system of economic sciences, the unity and difference between the subjects and methods of political economy and other components of economic theory.

Keywords: political economy; formation and development of political economy; Ukrainian economists of the XIX century; the origin of political economy in Ukraine; Kyiv political economy school; political economy as an educational discipline; Kharkiv political economy school

\section{References}

1. Gorkina; L.P. (2001). Tugan-Baranovs'ky’j $v$ ekonomichnij teoriyi ta istoriyi [TuganBaranovsky in the Economical Theory and History.]. K. [in Ukrainian].

2. Kornijchuk L.Ya. (2004). Istoriya ekonomichnoyi dumky` Ukrayiny` [History of economic thought of Ukraine]. K.: KNEU. [in Ukrainian].

3. Vasy`lyeva, R.X., Gorkina, L.P., Petrovs`ka, N.A. (1993). Istoriya ekonomichnoyi dumky` Ukrayiny` [History of economic thought of Ukraine]. K.: Ly'bid' [in Ukrainian].

4. Leonenko, P.M. (2004). Metodologichni aspekty' istoriyi ukrayins'koyi ekonomichnoyi dumky (XIX - XX st.) [Methodological aspects of the history of Ukrainian economic thought (XIX - XX centuries).]. K.: IAE UAAN [in Ukrainian].

5. Leonenko, P.M., Yuxy`menko, P.I. (2004). Ekonomichna istoriya [Economic history.]. K.: Znannya [in Ukrainian]. 
6. Kornijchuk, L.Ya., Tatarenko, N.O., Poruchny`k, A.M., Tkachenko, O.V., Ky`ry`lova, G.Yu. (2005) Istoriya ekonomichny'x uchen' [The history of economic studies]. K.: KNEU [in Ukrainian].

7. Koropecz ky`j I.S. (1993). Ukrayins`ki ekonomisty`XIX st. ta zaxidna nauka [Ukrainian economists of the XIX cent. and Western science.]. K. [in Ukrainian].

8. Bazy`levy`ch V. (2004). Istoriya ekonomichny`x uchen' [The history of economic studies]. K.: Znannya [in Ukrainian].

9. Shevchuk, V. (1996). Ukrayins`ka ekonomichna dumka na tli suchasnogo cy`vilizacijnogo rozvy'tku [Ukrainian economic thought on the background of modern civilization development.]. Collection of scholarly papers. / Published by the Ukrainian Free University in Munich. Reihe: Studia. Band 18. München L'viv, 48-66 [in Ukrainian].

10. Sheremet, A.D., Maydanchik, B.I. (1981). Aktualnyie voprosyi razvitiya ekonomicheskogo analiza v 80-e godyi [Actual issues of development of economic analysis in the 80's.]. Buhgalterskiy uchet. \# 6. S. 26-27 [in Ukrainian].

11. Politicheskaya ekonomiya: proshloe, nastoyaschee, buduschee. Chast I.: monograflya [Political economy: past, present, future.] (2014). K.: TsUL [in Russian].

12. Tarasevich, V.N., Geyts V.M. (2014)/ Politicheskaya ekonomiya: proshloe, nastoyaschee, buduschee. Chast II. monograflya [Political economy: past, present, future.].K.: TsUL [in Russian].

Received 29.05.2018

Received in revised form 15.06.2018

Accepted 20.06.2018 